\title{
Trophic impact and prey selection by crustacean zooplankton on the microbial communities of an oligotrophic coastal area (NW Mediterranean Sea)
}

\author{
Elisabetta Broglio, Enric Saiz*, Albert Calbet, Isabel Trepat, Miquel Alcaraz \\ Departament de Biologia Marina i Oceanografia, Institut de Ciències del Mar, CMIMA, CSIC, Passeig Marítim de la \\ Barceloneta 37-49, 08003 Barcelona, Catalunya, Spain
}

\begin{abstract}
Selection for ciliates in the presence of phytoplankton has been previously shown for some species of copepods. However, the factors determining preference for this heterotrophic prey and how crustacean zooplankton predation can affect the ciliate community are not yet fully understood. In this study, we investigated predation rates on phytoplankton and ciliates by the most abundant copepod and cladoceran species in a coastal area of the oligotrophic NW Mediterranean Sea monthly over an annual cycle. Three major results were apparent. Firstly, ciliates were important contributors to zooplankton diet, representing a median of 37 and $17 \%$ of the carbon intake, and 51 and $34 \%$ of the nitrogen intake for copepods and cladocerans, respectively. Secondly, ciliates were positively selected in most cases, this selection was species specific and apparently independent of phytoplankton concentration. And finally, in spite of the high clearance rates on ciliates, the impact of the crustacean community on the ciliate standing stock was low (median $2 \%$ ), suggesting a bottom-up control of the ciliate community.
\end{abstract}

KEY WORDS: Copepods $\cdot$ Cladocerans $\cdot$ Ciliates $\cdot$ Food web $\cdot$ NW Mediterranean

\section{INTRODUCTION}

Ciliates are important components of marine pelagic food webs (Azam et al. 1983, Sherr et al. 1986). They are significant consumers of pico- and nanoautotrophic production (Finlay \& Fenchel 1996) and, at the same time, represent a valuable food for zooplankton (Stoecker \& Capuzzo 1990). For these reasons, ciliates may constitute an important link between the microbial loop and higher trophic levels of the food chain (Sherr \& Sherr 1988).

Since the early 1990s, many studies have highlighted the potential role of ciliates and have reported high clearance rates on these organisms by marine zooplankton both in the field (e.g. Tiselius 1989, Fessenden \& Cowles 1994) and the laboratory (e.g. Stoecker \& Egloff 1987, Jonsson \& Tiselius 1990). Thus, ciliates appear to be significant prey items of zooplankton in very different trophic areas, ranging from rich upwelling zones and spring bloom situations (Fessenden \& Cowles 1994, Irigoien et al. 1998) to oligotrophic (Gifford \& Dagg 1991, Zeldis et al. 2002) and polar ecosystems (Atkinson 1996, Levinsen et al. 2000). Most studies have focused on copepods, showing that a variety of species, with very different feeding behaviours, are able to efficiently feed on them. At the small-scale, behavioural studies have revealed that ciliates are detected by mechanical perception (Jonsson \& Tiselius 1990, Saiz \& Kiørboe 1995, Kiørboe et al. 1996), and that ciliate behaviour plays a principal role in the ciliate-copepod interaction and selectivity patterns (Broglio et al. 2001).

However, some interesting questions on ciliatezooplankton interactions remain. For instance, the frequent lack of correlation observed in many field studies between in situ growth rates of zooplankton and the concentration of phytoplankton (e.g. Dam et al. 1994, Ohman \& Runge 1994, Saiz et al. 1999, Calbet et 
al. 2002a) is commonly used to argue that ciliates may be important to zooplankton diet. Yet, relatively few studies have paid attention to the actual nutritional contribution of ciliates as carbon and nitrogen sources for zooplankton metabolism, and compared them to the one supplied by phytoplankton ingestion (e.g. Froneman et al. 1996, Batten et al. 2001). Furthermore, it is scarcely known how ciliate contribution to crustacean zooplankton diet may vary by season, in which different zooplankton species and microbial communities occur.

A second aspect of interest in the trophic interactions between ciliates and zooplankton deals with feeding selection mechanisms. Copepods frequently exhibit higher clearance rates on ciliates than on phytoplankton (e.g. Gifford \& Dagg 1991, Fessenden \& Cowles 1994, Levinsen et al. 2000), a fact that has been attributed to positive selection patterns. What exactly determines this positive selection is not clear, and factors like food quality and encounter rates have been proposed (Jonsson \& Tiselius 1990, Stoecker \& Capuzzo 1990). However, the preference for a given food item could also be dependent on the availability of an alternative suitable prey, and switching responses may appear as well (Kiørboe et al. 1996, Gismervik \& Andersen 1997). Unfortunately, few field studies have considered these aspects.

Finally, little is known concerning the strength of the trophic control that zooplankton may exert on ciliate communities. Because of their nexus position, as both prey for zooplankton and top predators for other microbes, ciliates represent a crucial link within marine planktonic food webs. Empirical evidence up to now, however, indicates that copepods, the major component of mesozooplankton, in general, exert only low predation control on ciliate communities (e.g. Atkinson et al. 1996, Lonsdale et al. 2000, Batten et al. 2001). Nevertheless, most of these previous studies have been conducted in ecosystems not necessarily comparable to temperate oligotrophic conditions (e.g. polar and subpolar; Atkinson 1996, Lonsdale et al. 2000) and restricted to short periods of time, making it difficult to obtain a comprehensive picture of this control on a yearly basis.

These issues can be summarised in the following questions, which represent the main objectives of this study: (1) Are ciliates important contributors to the diet of zooplankton under natural conditions? (2) Is the reported preference for ciliates by zooplankton a mere consequence of their availability in the field, or does it depend on the presence of alternate prey? (3) Can predation by zooplankton control the ciliate community?

To address these questions, integrative work contemplating a broad spectrum of prey abundance and the study of the natural feeding behaviour of the dif- ferent groups (species) of zooplankters are needed. In this sense, field studies are essential tools. Even though they may not provide as much insight into the actual mechanism's driving processes, compared to laboratory experimentation under controlled conditions, they cope with natural diversity and variability and provide, thus, an ideal frame for further research. Here, we report on experiments on zooplankton feeding carried out in a nearshore station in the NW Mediterranean Sea, comprising a whole year round seasonal cycle, which then included a wide spectrum of ciliate and phytoplankton abundance. The zooplanktonic species encountered were the copepods Oithona spp., Paracalanus parvus, Clausocalanus spp., Temora stylifera, Euterpina acutifrons and Centropages typicus, and the cladocerans Evadne spinifera, Penilia avirostris and Podon spp. We quantified the contribution of ciliates, and small $(<5 \mu \mathrm{m})$ and large $(>5 \mu \mathrm{m})$ phytoplankton to the natural diet of these zooplankters, and determined their selectivity patterns and grazing impact on microbial communities.

\section{MATERIALS AND METHODS}

Field sampling. Monthly experiments were conducted, from May 1999 to July 2000, at a nearshore station located off Masnou (20 km north of Barcelona, Spain, NW Mediterranean). Water for experiments and for the assessment of the naturally occurring microbial community (phytoplankton and ciliates) was collected with a transparent bottle (15 1 capacity, 2 collections) from ca. $1 \mathrm{~m}$ depth. A $250 \mathrm{ml}$ subsample of the water collected was preserved immediately with $10 \%$ acidic Lugol's iodine solution for ciliate enumeration (Stoecker et al. 1994). Two $500 \mathrm{ml}$ water subsamples were kept in darkness for chlorophyll determination after arrival in the lab. The remaining water was transported to the laboratory to be used as natural planktonic community for feeding experiments, which started about $3 \mathrm{~h}$ after collection.

Zooplankton abundance was assessed by vertical tows, from near bottom (ca. $20 \mathrm{~m}$ ) to surface, using a hand-hauled $36 \mathrm{~cm}$ diameter plankton net $(53 \mu \mathrm{m}$ mesh size). Zooplankton samples were preserved with buffered formalin (4\% final concentration). Zooplankton for feeding experiments were collected by slow speed oblique tows using a Judai-Bogorov plankton net (200 $\mu \mathrm{m}$ mesh) with a 5 to $10 \mathrm{l}$ plastic bag as nonfiltering cod end to minimise organism damage and reduce sampling stress. Samples were kept in a cooler until return to the laboratory.

Phytoplankton biomass was estimated as chlorophyll concentration in 2 size fractions, $<5$ and $>5 \mu \mathrm{m}$. Aliquots of respectively 75 and $150 \mathrm{ml}$ of water were 
filtered onto Whatmann GF/F and $5 \mu \mathrm{m}$ pore-size polycarbonate membrane filters under low vacuum pressure $(<100 \mathrm{~mm} \mathrm{Hg})$, and the filters stored frozen at $-80^{\circ} \mathrm{C}$ until analysis. The size fraction $<5 \mu \mathrm{m}$ was estimated by the difference between total (GF/F) and $>5 \mu \mathrm{m}$ chlorophyll concentrations.

Grazing experiments. The experimental water was carefully poured into a $50 \mathrm{l}$ bucket and reverse-flow screened gently by submerging a $30 \mathrm{~cm}$ diameter PVC cylinder fitted with a $100 \mu \mathrm{m}$ mesh size bottom. By this procedure, predators $>100 \mu \mathrm{m}$ were eliminated from the experimental suspension. The experimental water was left ca. 30 min to allow the microplanktonic community to stabilise. Duplicate initial samples were taken for ciliate enumeration (acidic Lugol's iodine solution, $10 \%$ final concentration) and for chlorophyll analysis $(<5$ and $>5 \mu \mathrm{m})$. Then, $620 \mathrm{ml}$ screw-cap Pyrex bottles were gently filled with the water from inside the sieve $(<100 \mu \mathrm{m})$; special care was taken to avoid thorough stirring (i.e. bubble formation) while filling the bottles because the turbulent flow might have damaged microplankton. Each experiment consisted of 3 or 4 experimental bottles with predators (4 to 14 individuals, depending on the species size) and 4 bottles without predators (controls). To override nutrient enrichment effects due to zooplankton excretion in the grazing bottles, the experimental water (for all bottles) had been previously (right after reverse-flow sieving) amended with a nutrient mixture of $15 \mu \mathrm{M} \mathrm{NH}_{4} \mathrm{Cl}$ and $1 \mu \mathrm{M} \mathrm{Na}_{2} \mathrm{HPO}_{4}$. The bottles were incubated on a rotating plankton wheel $(0.2 \mathrm{rpm})$ in a temperaturecontrolled room at a similar temperature and light cycle to those of the day of collection.

After $24 \mathrm{~h}$, the contents of the bottles were gently filtered through a submerged $180 \mu \mathrm{m}$ sieve and samples for the assessment of ciliate abundance and chlorophyll concentration were treated as described above. The zooplankters remaining in the $180 \mu \mathrm{m}$ sieve were carefully transferred to a glass bowl, counted live under a stereomicroscope (dead organisms or those in poor condition were not included in later calculations) and then preserved in formalin $(4 \%$ final concentration) for later determination of size.

Sample processing and calculations. Chlorophyll was analysed fluorometrically. Filters were placed in tubes with $6 \mathrm{ml}$ of $90 \%$ acetone, and chlorophyll was extracted in darkness for ca. $24 \mathrm{~h}$ at $4^{\circ} \mathrm{C}$. Subsequently, fluorescence was measured (without acidification) with a Turner Design fluorometer. Chlorophyll concentration was transformed into phytoplankton carbon using a carbon-to-chlorophyll ratio of 30 (Delgado et al. 1992, Arin et al. 2002).

Ciliate abundance was estimated by settling $100 \mathrm{ml}$ samples in Utermöhl chambers for $48 \mathrm{~h}$. The whole sample was scanned under a Zeiss Axiovert
35 inverted microscope (200x) and cells were identified into broad taxonomic groups and logged in size categories.

To correct the ciliate abundance estimates for possible losses of ciliates due to both Lugol's preservation and water sample handling, we carried out in parallel an attempt to determine the degree of ciliate loss in our samples. To determine the factor of cell loss due to preservation with $10 \%$ acidic Lugol's iodine solution, we took 20 aliquots of $1 \mathrm{ml}$ of ciliates from a suspension of the ciliate Strombidium sulcatum (at a concentration of 20 to 25 ciliates $\mathrm{ml}^{-1}$ ), and counted them live under a microscope. To minimise counting error of live ciliates, the counts were repeated 4 times for each aliquot and average value computed. Counting error was low, with an average $\mathrm{CV}$ among replicates of $8 \%$ (range: 4 to $15 \%)$. At the same time, 3 aliquots $(50 \mathrm{ml})$ from the same Strombidium culture were fixed with $10 \%$ acidic Lugol's iodine solution and then counted under the microscope. Live counts differed significantly from the preserved samples ones (1-factor ANOVA: $F=34.9$, $\mathrm{p}<0.004$ ), with preservation in $10 \%$ Lugol resulting in a reduction of $30 \%$ in cell counts. This correction factor for $S$. sulcatum was assumed to be of general application and used to correct the ciliate abundance of this study, both for in situ abundance and grazing experiments.

Moreover, we also explored any possible detrimental effect of handling processes and nutrient addition on the estimates of ciliate abundance in our experiments. For each sampling date, we compared parallel aliquots of water samples preserved immediately after collection at sea with those from the same water after transportation to the laboratory, sieving, nutrient addition and gentle mixing while filling up grazing bottles (they actually corresponded to the start concentrations in grazing experiments). In both cases, two $250 \mathrm{ml}$ aliquots for each treatment were preserved with $10 \%$ acidic Lugol's iodine solution. Table 1 shows average values $( \pm \mathrm{SE})$ for both treatments (untreated and treated samples). No significant differences were found between treatments (mixed model 2-factor ANOVA, where sampling date was a random factor and untreated/treated sample a fixed factor; $F_{1,9}=0.34$, $\mathrm{p}>0.5$ ), indicating that neither time spent in reaching the lab from the sample site and setting-up the experiment $(3 \mathrm{~h}$ approximately) nor laboratory handling (addition of nutrients, sieving through a $100 \mu \mathrm{m}$ mesh, gentle mixing of water and filling of the experimental bottles) affected the ciliate abundance.

Ciliate biomass was calculated assuming $0.19 \mathrm{pg} \mathrm{C}$

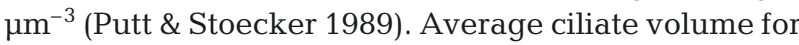
each experiment was estimated from pictures $(n=50)$ taken with a digital photo camera (DKC-CM30, Sony) attached to the microscope, and analysed on a Power 
Table 1. Ciliate abundance (average $\pm \mathrm{SE}$ ) of untreated samples (immediately fixed after collection) and treated samples (preserved ca. $3 \mathrm{~h}$ after sampling, following nutrient addition, sieving, mixing and filling of bottles). All samples were preserved with $10 \%$ acid Lugol's iodine solution. The values shown in this table are not corrected for the factor calculated to measure the loss of cells due to fixation

\begin{tabular}{|lrr|}
\hline Date & $\begin{array}{r}\text { Untreated } \\
\left({\text { cells })^{-1}}^{\text {) }}\right.\end{array}$ & $\begin{array}{c}\text { Treated } \\
\left.\text { cells ml }^{-1}\right)\end{array}$ \\
\hline May 99 & $3.6 \pm 0.53$ & $3.3 \pm 0.15$ \\
Jun 99 & $1.7 \pm 0.20$ & $1.0 \pm 0.10$ \\
Jul 99 & $13.2 \pm 1.04$ & $15.0 \pm 1.24$ \\
Aug 99 & $14.0 \pm 2.40$ & $14.7 \pm 1.66$ \\
Sep 99 & $1.1 \pm 0.07$ & $1.6 \pm 0.05$ \\
Feb 00 & $1.5 \pm 0.12$ & $1.9 \pm 0.20$ \\
Mar 00 & $3.8 \pm 0.10$ & $4.1 \pm 0.85$ \\
May 00 & $4.3 \pm 1.05$ & $3.7 \pm 0.12$ \\
Jun 00 & $17.5 \pm 1.72$ & $12.5 \pm 1.82$ \\
Jul 00 & $3.9 \pm 0.67$ & $3.4 \pm 0.07$ \\
& & \\
\hline
\end{tabular}

Macintosh computer with the NIH Image analysis software (National Institute of Health, Bethesda, MD, USA). The contour of the ciliates was outlined, the cell area measured, and the length and width of the cell automatically estimated assuming an ellipsoidal or spherical shape, depending on the species.

Zooplankton clearance and ingestion rates were calculated according to the equations of Frost (1972). Prior to computation, growth rates in control and grazing bottles were compared ( $t$-test, with or without correction for unequal variance). Clearance rates were computed when prey growth in control bottles was significantly higher than in grazing bottles. Due to high variability within replicates, on several occasions, differences between control and grazing bottles were either weakly significant or not significant, although computed clearance rates were in general positive and high. Conservatively, we opted to include these clearance values in the work, although pointing out when the estimates had a fully significant statistical value. When computing clearance rates, occasional replicates ( 7 cases in the whole study) which rendered negative values were levelled off to 0 . One experiment with Podon sp. deserves a special mention: here prey growth in control bottles was significantly lower than in the experimental ones, suggesting trophic cascade effects masking grazing. In this case, no clearance rates were computed (see 'Results').

Zooplankton biomass (as $\mu \mathrm{g}$ C) was estimated from species-specific length-weight relationships from the literature, assuming, when necessary, that carbon content is $40 \%$ of dry weight (Parsons et al. 1984a). The equations employed came from Uye \& Sano (1998) for Oithona sp., from Uye (1991) for Paracalanus sp., from
Chisholm \& Roff (1990) for Temora sp. and Clausocalanus sp., from Davis \& Alatalo (1992) for Centropages sp., from Satapoomin (1999) for Euterpina sp., from Walve \& Larsson (1999) for Evadne sp. and from Uye (1982) for Penilia avirostris and Podon sp. The equation used to determine the biomass of the whole copepod community (used to calculate the trophic impact, see 'Results') is also from Uye (1982).

Prey selectivity (i.e. the existence of certain prey that are ingested in a higher or lower proportion than expected from their field relative abundance) was evaluated in different ways. Although an acute difference in the clearance rates of a predator on different prey within an experiment may be indicative of selective feeding patterns, another visual way to approach selection, however, is the one by plotting the prey contribution to the zooplankton diet against its availability (Calbet et al. 2002b). In this kind of plot, values that fall above the line 1:1 are indicative of prey preference, whereas values falling below the line represent deterrence for the specific prey. We further determined prey selectivity patterns by using the Chesson's index of selectivity $(\alpha)$ corrected for food depletion (Chesson 1983):

$$
\alpha_{k}=\frac{\ln \left(r_{k} / p_{k}\right)}{\sum_{i}^{n} \ln \left(r_{i} / p_{i}\right)}
$$

where $r_{k}$ and $p_{k}$ are the proportion of prey class $k$ after and before the incubation, respectively, and $n$ is the number of prey classes. Neutral selection would result in a constant $\alpha_{i}=1 / n$. This index was chosen because it is prey density independent and permits the determination of whether prey items were ingested in higher or lower proportion of what would be expected due to their relative abundance in the field.

Unless otherwise stated, arithmetic means $\pm 1 \mathrm{SE}$ are shown. However, in some cases, median values and range are reported instead, due to the presence of very extreme values in the lower or upper ends of the range, which made arithmetic means less representative.

Calculation of the impact exerted by the crustacean zooplankton on the microbial community. The impact on the ciliate and phytoplankton standing stock exerted by the studied copepods and cladocerans was determined from their abundance and clearances rates assuming a homogenous ciliate distribution in the water column. We also calculated the potential impact that the whole crustacean zooplankton community might exert on the microbial assemblage, assigning an average clearance rate estimate (on a per biomass basis) from the measured clearance rates for copepods and cladocerans to, respectively, the whole copepod and cladoceran community. 


\section{RESULTS}

\section{Seasonal plankton patterns}

Total chlorophyll concentration ranged from 0.28 to $4.38 \mu \mathrm{g} \mathrm{chl} \mathrm{l^{-1 }}$ over the period studied. Three phytoplankton blooms were observed: in summer (July 1999, $3.5 \mu \mathrm{g} \mathrm{chl} \mathrm{l}^{-1}$ ), in winter (February 2000, $4.3 \mu \mathrm{g} \mathrm{chl} \mathrm{l}^{-1}$ ) and in spring (April and May 2000, $4.4 \mu \mathrm{g} \mathrm{chl}^{-1}$ ). On

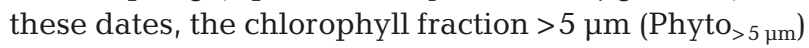
dominated the phytoplankton community (Fig. 1), although concurrent peaks of the chlorophyll $<5 \mu \mathrm{m}$ $\left(\mathrm{Phyto}_{<5} \mu \mathrm{m}\right)$ were also observed. On the other dates, the chlorophyll concentration averaged $1.1 \pm 0.18 \mu \mathrm{g}$ $\mathrm{l}^{-1}$ and was often dominated by the fraction $<5 \mu \mathrm{m}$ cells.

Ciliate abundance averaged $7( \pm 2 \mathrm{SE})$ cells $\mathrm{ml}^{-1}$ over the year, with median value of $4.3 \mathrm{cells} \mathrm{ml}^{-1}$. Maximum values were found in summer (18.2 and $24.1 \mathrm{cells} \mathrm{ml}^{-1}$ in August 1999 and June 2000, respectively) and minimum ones from September 1999 to February 2000 (1.8 cells ml ${ }^{-1}$ on average). The highest ciliate abundance occurred approximately 1 mo after the phytoplankton blooms (Fig. 1). A minor increase of ciliate concentration also followed the winter phytoplankton bloom of February. The ciliate community was numerically dominated by small ( $<20 \mu \mathrm{m}$ length) aloricated ciliates (Fig. 2). Overall, Strombidium spp. and Strobilidium spp. represented, on average, more than $70 \%$ of the ciliate community, while loricated ciliates (tintinnids) represented on average only $4.4 \%$ of the community over the year. Other numerically important genera were Mesodinium, Laboea, Tontonia, Strombi-

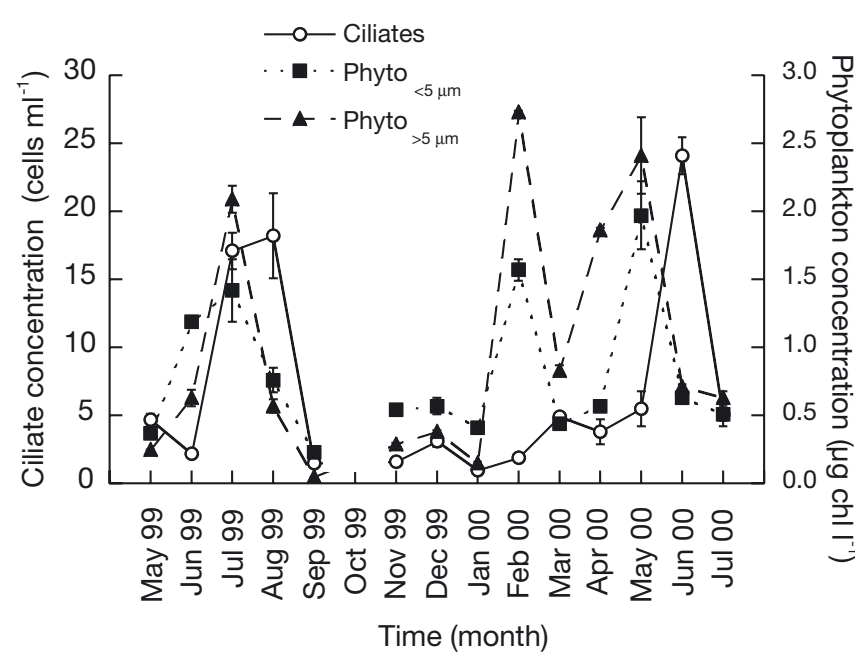

Fig. 1. Temporal evolution of ciliate and phytoplankton (as chlorophyll, $<5$ and $>5 \mu \mathrm{m}$ ) concentrations at the study site. Means of 2 replicates are shown. Bars indicate SE. No sampling took place in October 1999

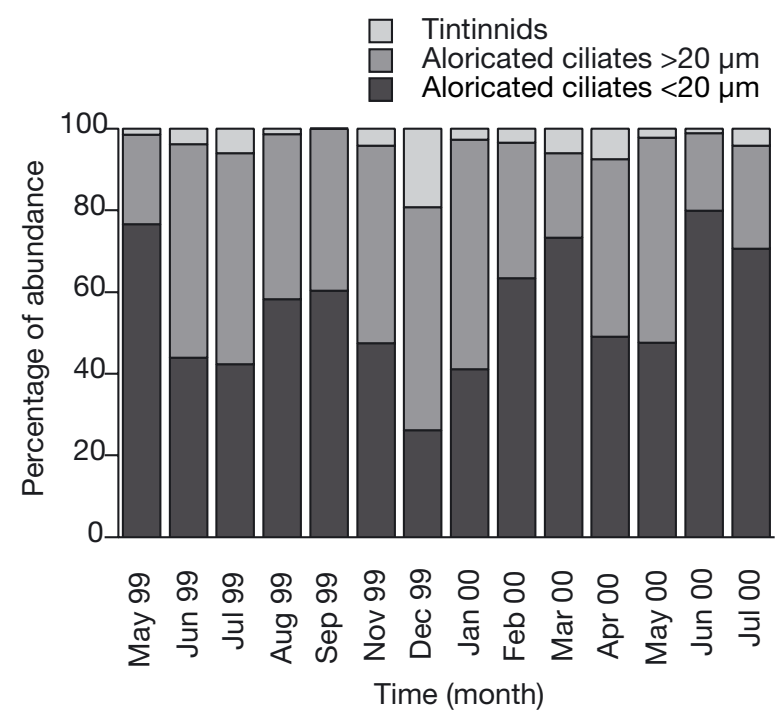

Fig. 2. Relative abundance (as \%) of tintinnid and aloricated ciliates ( $>20$ and $<20 \mu \mathrm{m}$ maximum length) over the period studied

dinopsis, Askenasia, Pleuronema, Cyclidium and Balanion. Among these genera, Mesodinium was the most abundant, representing, on average, $12 \%$ of the ciliate community over the year.

\section{Feeding experiments}

Table 2 provides information on dates, temperature, zooplankton genera, and initial phytoplankton and ciliate concentrations in the experiments conducted.

In terms of biomass (as $\mu \mathrm{C} \mathrm{Cl}^{-1}$ ), ciliates represented a low percentage of the available potential food resources (i.e. ciliates + Phyto $_{>5} \mu \mathrm{m}+$ Phyto $_{<5} \mu \mathrm{m}$ ), comprising only $17 \% \quad( \pm 5 \quad \mathrm{SE})$ of available carbon. Phyto $_{>5} \mu \mathrm{m}$ and Phyto $<5$ m contributed similarly to the carbon pool, being on average $41 \%( \pm 6 \mathrm{SE})$ and $42 \%$ $( \pm 5.7 \mathrm{SE})$ of the available carbon, respectively. However, during summertime (Expts 3, 4 and 9), ciliate importance increased, accounting for between 20 and $53 \%$ of the biomass of the total microbial community. The biomass of ciliates was correlated with neither Phyto $_{>5 \mu \mathrm{m}}$ nor Phyto $<5 \mu \mathrm{m}$ ( $\mathrm{p}>0.8$ in both cases), although both phytoplankton fractions were significantly correlated with one another $(r=0.79, p<0.007$, $\mathrm{n}=10$ ).

Zooplankton clearance rates were very variable both among and within species (Table 3 ). Clearance rates on ciliates ranged from 4 to $110 \mathrm{ml}$ ind..$^{-1} \mathrm{~d}^{-1}$ for copepods (median: $26.4 \mathrm{ml}$ ind. ${ }^{-1} \mathrm{~d}^{-1}$ ) and 4 to $33 \mathrm{ml}$ ind..$^{-1} \mathrm{~d}^{-1}$ for cladocerans (median: $17.6 \mathrm{ml}$ ind. ${ }^{-1} \mathrm{~d}^{-1}$ ). Copepod clearance rates on phytoplankton were usually lower 
Table 2. Experiments conducted. Date, water temperature, genera of predator studied and initial ciliate and phytoplankton abun-

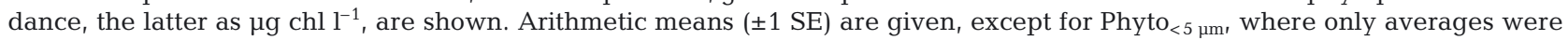
computed as Phyto $_{\text {total }}-$ Phyto $_{>5} \mu \mathrm{m}$

\begin{tabular}{|c|c|c|c|c|c|c|}
\hline Expt & Date & $\begin{array}{c}\text { Temperature } \\
\left({ }^{\circ} \mathrm{C}\right)\end{array}$ & Predator & $\begin{array}{c}\text { Ciliates } \\
\left(\text { cells } \mathrm{ml}^{-1}\right)\end{array}$ & $\begin{array}{l}\text { Phyto }_{<5 \mu \mathrm{m}} \\
\left(\mu \mathrm{ghl} \mathrm{l}^{-1}\right)\end{array}$ & $\begin{array}{l}\text { Phyto }_{>5 \mu \mathrm{m}} \\
\left(\mu \mathrm{ghl}^{-1}\right)\end{array}$ \\
\hline 1 & May 99 & 18.0 & Evadne, Oithona, Paracalanus & $3.9(0.25)$ & 0.4 & $0.3(0.01)$ \\
\hline 2 & Jun 99 & 20.7 & Oithona, Paracalanus & $1.3(0.1)$ & 1.3 & $0.5(0.01)$ \\
\hline 3 & Jul 99 & 22.2 & Paracalanus, Penilia & $19.4(1.6)$ & 1.4 & $2.1(0.15)$ \\
\hline 4 & Aug 99 & 24.0 & Paracalanus & $19.1(2.2)$ & 0.7 & $0.6(0.05)$ \\
\hline 5 & Sep 99 & 21.8 & Clausocalanus, Penilia, Temora & $2(0.1)$ & 0.2 & $0.04(0.00)$ \\
\hline 6 & Feb 00 & 12.5 & Centropages, Euterpina, Podon & $2.5(0.3)$ & 0.7 & $1.6(0.02)$ \\
\hline 7 & Mar 00 & 14.0 & Euterpina, Evadne, Podon & $5.3(1.1)$ & 0.3 & $0.9(0.02)$ \\
\hline 8 & May 00 & 18.0 & Centropages, Oithona & $4.8(0.2)$ & 1.9 & $2.8(0.15)$ \\
\hline 9 & Jun 00 & 23.1 & Centropages, Euterpina, Oithona, Penilia & $16.3(2.4)$ & 0.7 & $0.7(0.01)$ \\
\hline 10 & Jul 00 & 23.1 & Clausocalanus, Oithona, Penilia, Temora & $4.5(0.1)$ & 0.6 & $0.6(0.07)$ \\
\hline
\end{tabular}

than on ciliates, with median values of $6.3 \mathrm{ml}$ ind. ${ }^{-1} \mathrm{~d}^{-1}$ for Phyto $_{<5 \mu \mathrm{m}}$ and $10 \mathrm{ml}$ ind.$^{-1} \mathrm{~d}^{-1}$ for Phyto $>5 \mu \mathrm{m}$. Cladoceran clearance rates on phytoplankton were, in gen-

Table 3. Clearance rates on ciliates, phytoplankton $<5 \mu \mathrm{m}\left(\right.$ Phyto $\left._{<5} \mu \mathrm{m}\right)$ and phytoplankton $>5 \mu \mathrm{m}\left(\right.$ Phyto $\left._{>5} \mu \mathrm{m}\right)$ by the different copepod and cladoceran species studied. Average values $( \pm 1 \mathrm{SE})$ are shown. ${ }^{*}$ Cases when growth rates in the experimental bottles were significantly different $(\mathrm{p}<0.05, t$-test) from growth rates in the control bottles. When growth in control bottles was significantly lower than in experimental bottles, suggesting trophic cascade effects masking zooplankton grazing, clearance rates were not determined (nd)

\begin{tabular}{|c|c|c|c|c|}
\hline Expt & Species & $\begin{array}{c}\text { Ciliates } \\
\left(\mathrm{ml} \text { ind } .^{-1} \mathrm{~d}^{-1}\right)\end{array}$ & $\begin{array}{l}\text { Phyto }_{<5} \mu \mathrm{m} \\
\left(\mathrm{ml} \mathrm{ind}^{-1} \mathrm{~d}^{-1}\right)\end{array}$ & 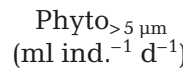 \\
\hline & Copepods & & & \\
\hline \multirow[t]{2}{*}{1} & Oithona spp. & $26(6)^{*}$ & 0 & $1(1)$ \\
\hline & Paracalanus parvus & $73(12)^{*}$ & $7(3)$ & $20(2)^{*}$ \\
\hline \multirow[t]{2}{*}{2} & Oithona spp. & $21(3)^{*}$ & 0 & $1(0.4)$ \\
\hline & P. parvus & $58(6)^{*}$ & $1(1)$ & $24(5)^{*}$ \\
\hline 3 & P. parvus & $23(7)^{*}$ & $39(38)$ & $6(2)$ \\
\hline 4 & P. parvus & $28(7)$ & $7(3)$ & $33(4)^{*}$ \\
\hline \multirow[t]{2}{*}{5} & Clausocalanus spp. & $110(5)^{*}$ & $6(3)$ & $10(2)^{*}$ \\
\hline & Temora stylifera & $103(21)^{*}$ & $7(4)$ & $42(9)^{*}$ \\
\hline \multirow[t]{2}{*}{6} & Euterpina acutifrons & $15(5)$ & $13(9)$ & $5(2)$ \\
\hline & Centropages typicus & $79(23)^{*}$ & $18(11)$ & $44(14)^{*}$ \\
\hline 7 & E. acutifrons & $21(5)^{*}$ & $11(2)$ & $11(1)^{*}$ \\
\hline \multirow[t]{2}{*}{8} & C. typicus & $76(6)^{*}$ & nd & $14(5)^{*}$ \\
\hline & Oithona spp. & $5(5)$ & $1(1)$ & $6(3)$ \\
\hline \multirow[t]{3}{*}{9} & C. typicus & $90(6)^{*}$ & 0 & $16(1)^{*}$ \\
\hline & E. acutifrons & $4(4)$ & $1(1)$ & $2(1)$ \\
\hline & Oithona spp. & $8(6)$ & 0 & $1(0.2)^{*}$ \\
\hline \multirow[t]{4}{*}{10} & Clausocalanus spp. & $37(7)^{*}$ & $6(3)$ & $6(1)^{*}$ \\
\hline & Oithona spp. & $17(14)$ & $7(7)$ & $1(1)$ \\
\hline & T. stylifera & $24(5)^{*}$ & $16(2)$ & $30(2)^{*}$ \\
\hline & Cladocerans & & & \\
\hline 1 & Evadne spinifera & $33(3)^{*}$ & 0 & $1(1)$ \\
\hline 3 & Penilia avirostris & $23(2)^{*}$ & 0 & $6(4)$ \\
\hline 5 & P. avirostris & $17(10)$ & $15(2)^{*}$ & 0 \\
\hline 6 & Podon spp. & $23(17)$ & $64(26)$ & $2(2)$ \\
\hline \multirow[t]{2}{*}{7} & E. spinifera & $4(2)$ & $16(6)^{*}$ & $0.4(0.4)$ \\
\hline & Podon spp. & nd & $26(5)$ & $4(2)$ \\
\hline 9 & $P$ avirostris & $18(11)$ & $6(3)$ & $10(1)^{*}$ \\
\hline 10 & $P$ avirostris & $8(1)$ & $2(2)$ & $4(2)$ \\
\hline
\end{tabular}

eral, lower than on ciliates as well. For Evadne spinifera and Penilia avirostris, feeding rates were up to $16 \mathrm{ml}$ ind. ${ }^{-1} \mathrm{~d}^{-1}$ on Phyto $_{<5}$ m and up to $10 \mathrm{ml}$ ind. ${ }^{-1} \mathrm{~d}^{-1}$ on Phyto $_{>5}$ um, while clearance rates of up to $33 \mathrm{ml}$ ind..$^{-1} \mathrm{~d}^{-1}$ were observed upon ciliates (Table 3). Among cladocerans, Podon sp. showed a contrasting feeding pattern, with apparently higher clearance rates on Phyto $_{<5} \mu \mathrm{m}$ than on ciliates.

Table 4 shows the ingestion rates for the different experiments. Values were very variable, from very low ingestion rates up to values of $2000 \mathrm{ng} \mathrm{C}$ ind. ${ }^{-1}$ $\mathrm{d}^{-1}$, representing daily food rations between 3 and $101 \%$ and between 10 and $151 \%$ of the body carbon for copepods and cladocerans, respectively (Fig. 3).

For copepods, the total carbon intake was correlated with the total carbon availability (i.e. ciliates + Phyto $_{>5} \mu \mathrm{m}+$ Phyto $\left._{<5 \mu \mathrm{m}}\right)$ in the experiments $(\mathrm{r}=0.81$, $\mathrm{p}<0.001, \mathrm{n}=19$ ). Ciliate carbon contributed between 2.5 and $92.7 \%$ of the total C intake of copepods (median $37 \%$, Fig. 3). When considered separately, copepod ingestion rates (as \% body $\mathrm{C}$ ingested $\mathrm{d}^{-1}$ ) on ciliates and Phyto $_{>5} \mu \mathrm{m}$ were significantly correlated with their corresponding prey abundance (respectively, $\mathrm{r}=0.686, \mathrm{p}<$ 0.002, $\mathrm{n}=19$ and $\mathrm{r}=0.884, \mathrm{p}<0.001$, $\mathrm{n}=19) ;$ however, no correlation ( $p>0.8$ ) was found between the ingestion and concentration of $\mathrm{Phyto}_{<5} \mu \mathrm{m}$. The copepod ingestion rate of ciliates in terms of carbon was correlated with neither the carbon ingestion rates of Phyto $_{>} \mu \mathrm{m}$ nor that of $\mathrm{Phyto}_{<5} \mu \mathrm{m}(\mathrm{p}>0.3)$. 
For cladocerans, the few number of observations precluded robust statistics. The total carbon intake was correlated with the total carbon availability (i.e. ciliates + Phyto $_{>5} \mu \mathrm{m}+$ Phyto $_{<5}$ umi $\mathrm{r}=0.928, \mathrm{p}<0.001$, $\mathrm{n}=8$ ), but the significance of this relationship disappeared when one influential observation (Expt 3, Penilia avirostris) was removed from the analysis $(\mathrm{r}=0.702, \mathrm{p}>0.07, \mathrm{n}=7$ ). The cladoceran ingestion rates on ciliates and $\mathrm{Phyto}_{>5} \mu \mathrm{m}$ were also correlated with the respective concentrations of ciliates and

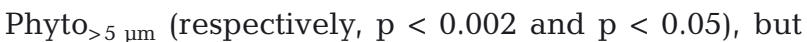
again these statistical relationships disappeared after removing the influential observation mentioned above ( $p>0.05$ in both cases).

\section{Selection patterns}

Fig. 4 shows the prey contribution to zooplankton diet as function of its relative availability. In spite of the dispersion of the data, it appears obvious that, overall, the majority of zooplankton species studied showed feeding selection for ciliates (i.e. most values are above the 1:1 line). In contrast, Phyto $_{<5} \mu \mathrm{m}$ seemed to be consumed at lower rates than expected from relative abundance (i.e. negative selection), whereas for Phyto $_{>5} \mu \mathrm{m}$, there was a scattered response and several species appeared to change selection patterns along the year (see below).

One must be aware, however, that selection may depend to a large extent not only on the proportion of prey but also on the absolute value of prey availability, which could partially explain the variability in response within and between species. Fig. 5 presents a visual summary of the results previously considered in combination with prey absolute concentration (focusing on the prey ingested prevalently, either ciliates and/or Phyto $>5$ mi only data for copepods is considered) and Chesson's index (Chesson 1983). This figure gives an idea, for the different species analysed, of the changes in their prey selection patterns as a function of prey availability changes through the seasons. It might be expected, in fact, that some predator might shift its prey type prefer-

Table 4. Ingestion rates, given as ng $\mathrm{C}$ ind.$^{-1} \mathrm{~d}^{-1}$, on ciliates, Phyto $\mathrm{t}_{5} \mu \mathrm{m}$ and Phyto $>5 \mu \mathrm{m}$ by the different copepod and cladoceran species. Average values $( \pm 1$ SE) are shown. Average predator carbon estimates are also indicated. nd $=$ not determinable (see legend of Table 3)

\begin{tabular}{|c|c|c|c|c|c|}
\hline Expt & Species & $\begin{array}{l}\text { Predator carbon } \\
\quad\left(\text { ng } C \text { ind } .^{-1}\right)\end{array}$ & $\begin{array}{c}\text { Ciliates } \\
\text { (ng C ind. } .^{-1} \mathrm{~d}^{-1} \text { ) }\end{array}$ & $\begin{array}{c}\text { Phyto }_{<5 \mu m} \\
\text { (ng C ind }{ }^{-1} \mathrm{~d}^{-1} \text { ) }\end{array}$ & $\begin{array}{c}\text { Phyto }_{>5} \mu \mathrm{m} \\
\text { (ng C ind. }{ }^{-1} \mathrm{~d}^{-1} \text { ) }\end{array}$ \\
\hline & Copepods & & & & \\
\hline \multirow[t]{2}{*}{1} & Oithona spp. & 570 & $164(34)$ & 0 & $13(13)$ \\
\hline & Paracalanus parvus & 1975 & $387(45)$ & $94(37)$ & $230(20)$ \\
\hline \multirow[t]{2}{*}{2} & Oithona spp. & 570 & $26(3)$ & 0 & $12(7)$ \\
\hline & $P$ parvus & 1932 & $62(4)$ & $32(19)$ & $372(62)$ \\
\hline 3 & P. parvus & 2298 & $684(159)$ & $654(614)$ & $821(310)$ \\
\hline 4 & P. parvus & 2343 & $539(121)$ & $118(60)$ & $629(53)$ \\
\hline \multirow[t]{2}{*}{5} & Clausocalanus spp. & 14106 & $61(1.4)$ & $40(21)$ & $16(3)$ \\
\hline & Temora stylifera & 6699 & $61(9)$ & $47(24)$ & $59(10)$ \\
\hline \multirow[t]{2}{*}{6} & Euterpina acutifrons & 682 & $58(18)$ & $238(157)$ & $230(116)$ \\
\hline & Centropages typicus & 2942 & $258(57)$ & $351(211)$ & 1987 (533) \\
\hline 7 & E. acutifrons & 682 & $54(11)$ & $123(21)$ & $342(15)$ \\
\hline \multirow[t]{2}{*}{8} & C. typicus & 1633 & $169(4)$ & nd & $1327(446)$ \\
\hline & Oithona spp. & 660 & $17(17)$ & $79(79)$ & $573(297)$ \\
\hline \multirow[t]{3}{*}{9} & C. typicus & 5228 & $1507(50)$ & 0 & 405 (13) \\
\hline & E. acutifrons & 689 & $118(106)$ & $25(25)$ & $63(21)$ \\
\hline & Oithona spp. & 510 & $200(140)$ & 0 & $30(6)$ \\
\hline \multirow[t]{4}{*}{10} & Clausocalanus spp. & 8743 & $180(20)$ & $100(57)$ & $205(34)$ \\
\hline & Oithona spp. & 990 & $84(58)$ & $112(112)$ & $29(29)$ \\
\hline & T. stylifera & 3144 & $132(26)$ & $273(25)$ & $853(47)$ \\
\hline & Cladocerans & & & & \\
\hline 1 & Evadne spinifera & 595 & $208(14)$ & 0 & $16(16)$ \\
\hline 3 & Penilia avirostris & 1001 & 696 (66) & 0 & $812(483)$ \\
\hline 5 & P. avirostris & 1053 & $13(6.8)$ & $96(11)$ & 0 \\
\hline 6 & Podon spp. & 2838 & $82(58)$ & 1078 (433) & $85(85)$ \\
\hline \multirow[t]{2}{*}{7} & E. spinifera & 670 & $10(7)$ & $173(66)$ & $12(12)$ \\
\hline & Podon spp. & 2838 & nd & $263(45)$ & $139(75)$ \\
\hline 9 & $P$. avirostris & 1408 & $428(240)$ & $103(46)$ & $260(32)$ \\
\hline 10 & $P$ avirostris & 1298 & $50(9)$ & $35(35)$ & $142(74)$ \\
\hline
\end{tabular}



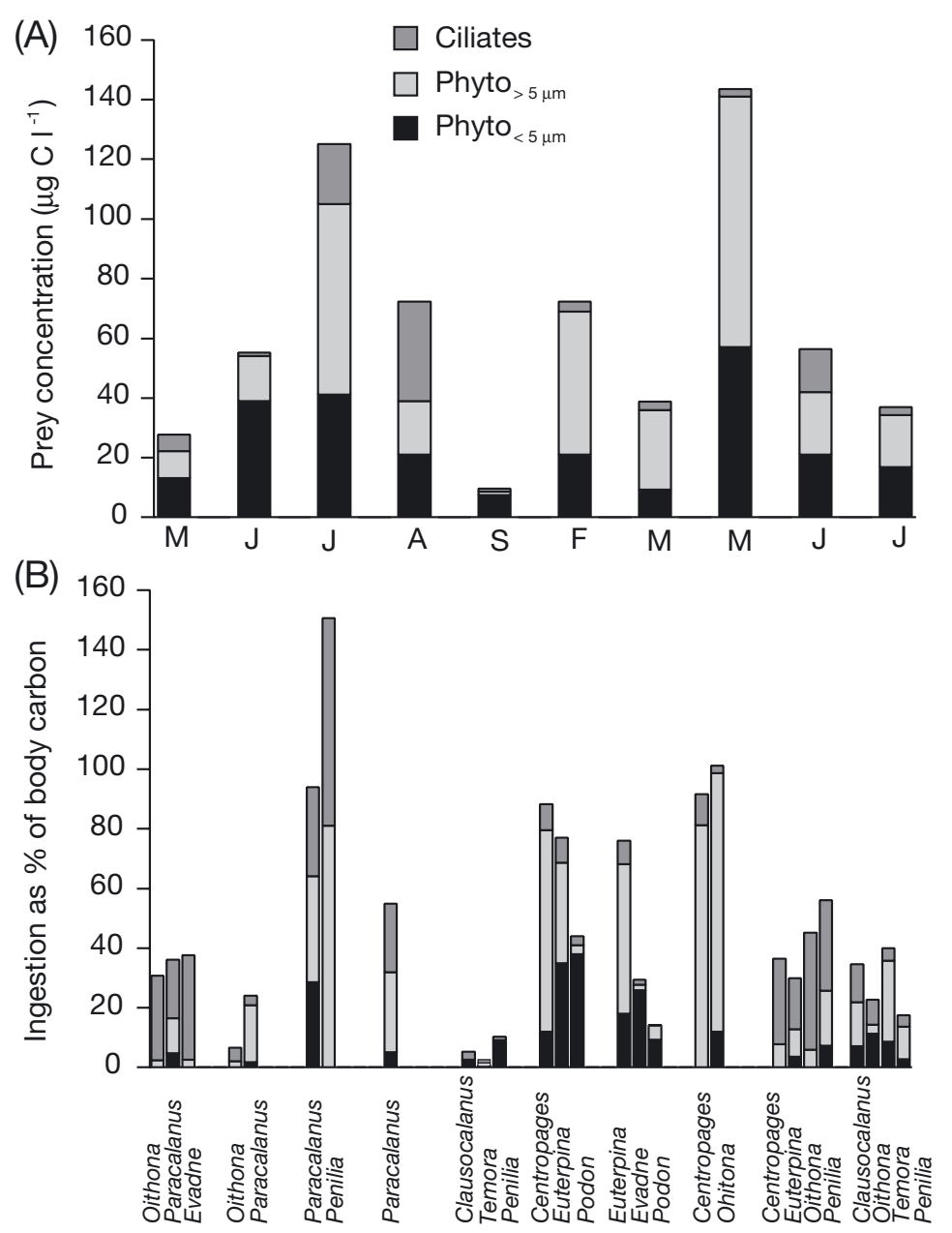

$\begin{array}{lllllllllll}\text { Expt } & 1 & 2 & 3 & 4 & 5 & 6 & 7 & 8 & 9 & 10 \\ \text { Month } & \mathrm{M} & \mathrm{J} & \mathrm{J} & \mathrm{A} & \mathrm{S} & \mathrm{F} & \mathrm{M} & \mathrm{M} & \mathrm{J} & \mathrm{J}\end{array}$

Fig. 3. (A) Initial biomass abundance of potential prey (ciliates, Phyto $_{>5} \mu \mathrm{m}$ and Phyto $_{<5} \mu \mathrm{m}$ ) and (B) relative prey ingestion by zooplankton species ence to another prey type if this last one becomes much more abundant. While the values obtained with the Chesson's index for the different experiments are given in Table 5, in Fig. 5, the positive selection for ciliates and/or Phyto $_{>5} \mu \mathrm{m}$ is shown, in correspondence with the prey availability along the year. Particular attention is given to the species whose diet and selection patterns were studied both in periods of low Phyto $_{>5} \mu \mathrm{m}$ concentration (corresponding with different ciliate concentration, Expts 1, 2, 4, 5, 7, 9 and 10) and during phytoplankton blooms dominated by the fraction $>5 \mu \mathrm{m}$, characterised also by either low or high concentration of ciliates (Expts 6 and 8, and Expt 3, respectively). Those species are Centropages typicus, Clausocalanus spp., Euterpina acutifrons, Oithona spp., Paracalanus parvus and Temora stylifera. Among them, only $C$. typicus and Oithona spp. showed a change in prey selectivity, being Phyto $_{>5} \mu \mathrm{m}$ selected positively together with ciliates during the phytoplankton blooms (Expts 8 and 6 , respectively). In no case, did a shift from positive selection for ciliates to positive selection exclusively for phytoplankton occur. Furthermore, the behaviour of C. typicus in terms of selection was not consistent, since its shared preference for ciliates and phytoplankton did not appear during Expt 8, when Phyto $_{>}$um concentration was even higher than in Expt 6. It seems thus that the studied species did not show any trend of change in prey selectivity (from positive selection only for ciliates to positive selection for Phyto $_{>5} \mu \mathrm{m}$ ) depending on prey concentration.
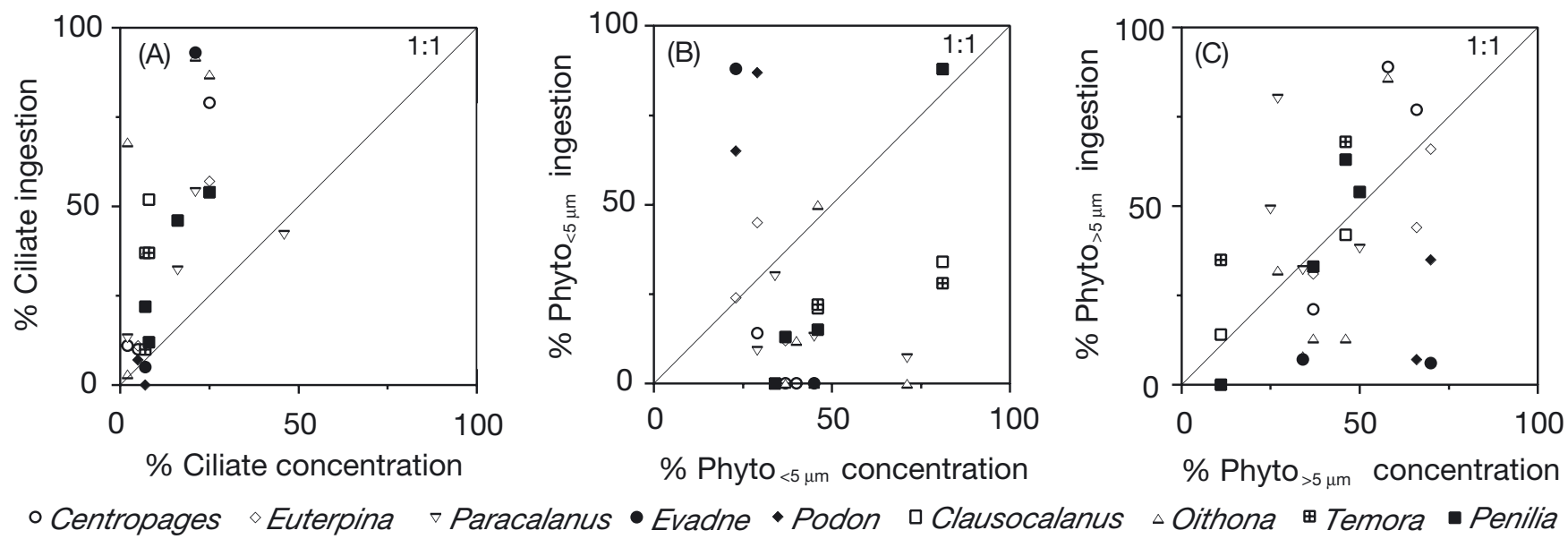

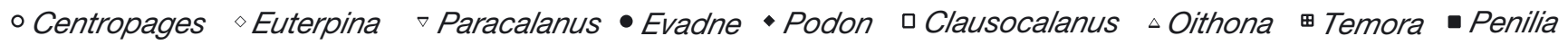

Fig. 4. Relative presence of a certain prey in the diet of zooplankton as a function of its relative abundance in the water. Data above the 1:1 line indicate positive feeding selection for that prey. (A) Ciliates, (B) Phyto $<5$ m, (C) Phyto $>5 \mu \mathrm{m}$ 


\section{Crustacean zooplankton grazing impact}

The crustacean studied species daily cleared from 0.02 to $4 \%$ (median: $0.5 \%$ ) of the ciliate standing stock through the period of study (Table 6), whereas the impact on phytoplankton standing stock was lower $\left(\right.$ Phyto $_{<5} \mu \mathrm{m}$ : median at $0.06 \%$, range: 0.01 to $0.7 \%$; Phyto $>5 \mu \mathrm{m}$ : median at $0.12 \%$, range: 0.01 to $1 \%$ ). The potential impact estimated for the whole copepod and cladoceran community was similarly low, and would result in a reduction of 0.5 to $7 \%$ (median: $2.4 \%$ ) of the ciliate standing stock through the year (Table 6), while the impact on phytoplankton standing stock would fluctuate from 0.01 to $0.86 \%$ for $\mathrm{Phyto}_{<5} \mu \mathrm{m}$ (median at $0.17 \%$ ), and from 0.02 to $0.84 \%$ for Phyto $_{>5}$ m (median at $0.34 \%$ ).

\section{DISCUSSION}

Our experiments over a yearly cycle permitted us to explore the trophic interactions between ciliates and a series of zooplankton species under quite different trophic situations, varying from communities dominated by Phyto $>5 \mu \mathrm{m}$ (Expts 3,6 and 8), to communities with similar concentrations of both Phyto $_{>5 \mu \mathrm{m}}$ and ciliates (Expts 4 and 9), to periods of very scarce availability of both prey types (Expt 5) and to transitional periods with low phytoplankton and ciliate concentrations (Expts 1, 2, 7 and 10). In this study, mean and maximum values of ciliate and phytoplankton standing stocks found, as well as ciliate composition, were typical of Mediterranean coastal waters (Perez et al. 1997, Vaqué et al. 1997, Pitta \& Giannakourou 2000, Modigh 2001).

\section{Contribution of ciliates to zooplankton food ration}

The total carbon ingestion rates for copepods observed in this study were variable, $50 \%$ of data comprising daily food rations between 24 and $77 \%$ of the body carbon. Maximum carbon intakes (77 to $101 \%$ body $\mathrm{C} \mathrm{d}^{-1}$ ) occurred in periods where Phyto $>5$ m dominated the carbon standing stock (Expts 3,6 and 8), whereas minimum intakes occurred in situations of very scarce availability of both phytoplankton and ciliates (Expt 5). However, these values were still quite below satiation determined in the laboratory for similarly sized copepods (Acartia tonsa, $180 \%$ body $\mathrm{C} \mathrm{d}^{-1}$, Kiørboe et al. 1985; Temora longicornis, $170 \%$ body $\mathrm{C}$ $\mathrm{d}^{-1}$, Klein Breteler et al. 1990), indicating that cope-

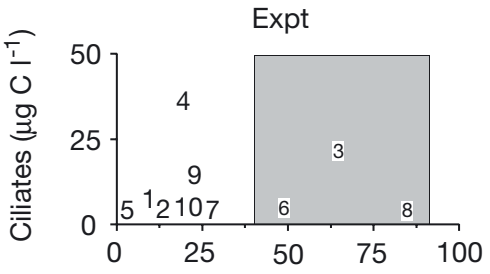

Positive selection for:

- Ciliates

口 Phyto $_{>5 \mu \mathrm{m}}$

v Ciliates and Phyto $>5 \mu \mathrm{m}$
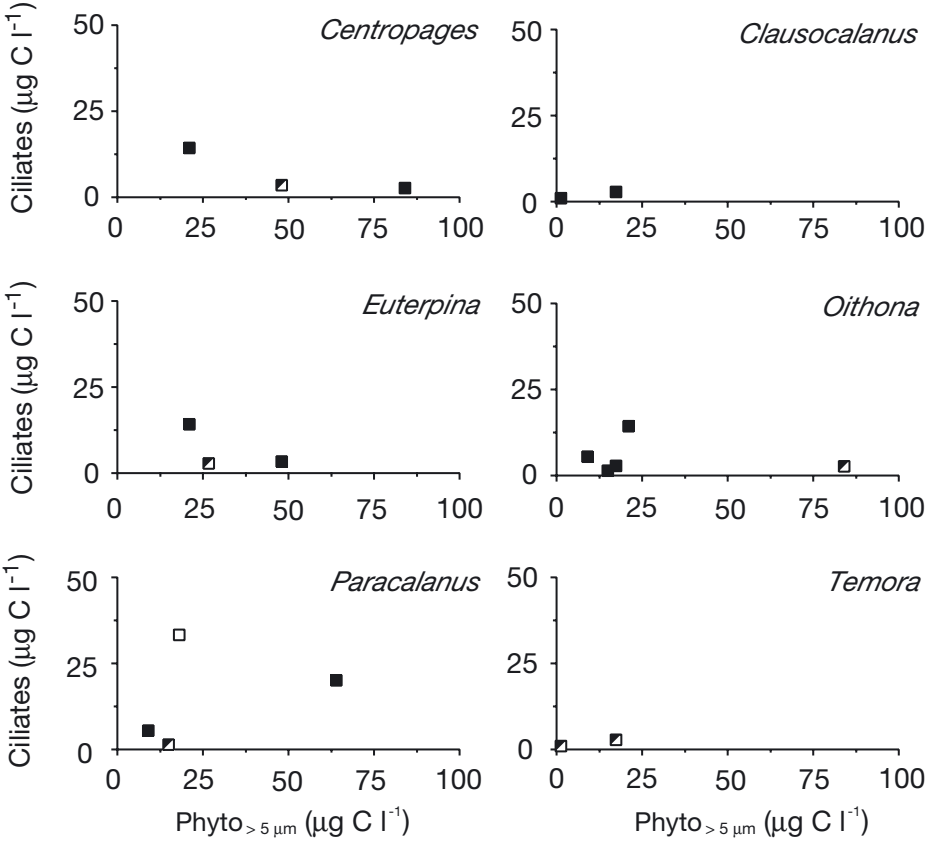

Fig. 5. Chesson's selectivity index for the copepod species studied as a function of prey availability. Only positive selection for either ciliates, Phyto $>5 \mu \mathrm{m}$ or both is shown. Symbols are placed in the corresponding positions of the relative abundance of Phyto $>5 \mu \mathrm{m}$ and ciliates for each experiment. For the sake of interpretation, one graph (top, left) shows the number of each experiment positioned as a function of the corresponding prey availability; the grey square highlights the phytoplankton bloom situations

pods appeared to be at least moderately food limited. The significant correlation between prey availability (ciliates and Phyto $_{>5} \mu \mathrm{m}$ ) and copepod ingestion rates also supports the view that copepods could be food limited on most occasions. We cannot exclude, however, the possibility that other possible food sources not considered in the present study (e.g. other heterotrophic prey and/or detritus) may have contributed to increase our daily food rations estimates. Regarding cladocerans, their daily $\mathrm{C}$ rations also may suggest food limitation throughout most periods of the study ( $50 \%$ of values between food rations of 15 and $53 \%$ of body $\mathrm{C} \mathrm{d}^{-1}$ ).

In spite of representing, on average, only $15 \%$ (range: 3 to $51 \%$ ) of total prey carbon available, ciliates made a significant contribution to the total car- 
Table 5. Chesson's index values (see 'Materials and methods' section) calculated for the different zooplankters studied for their selectivity patterns with respect to 3 potential prey: ciliates, Phyto $_{>5} \mu \mathrm{m}$ and $\mathrm{Phyto}_{<5 \mu \mathrm{m}}$. Values above $0.33(=1 / \mathrm{n}$ classes) indicate positive selection for that prey, while values below 0.33 indicate negative selection for that prey

\begin{tabular}{|c|c|c|c|c|c|c|}
\hline \multirow{2}{*}{$\begin{array}{l}\text { Predator } \\
\text { Copepods }\end{array}$} & \multirow[t]{2}{*}{ Prey } & \multicolumn{5}{|c|}{ - Chesson's index, Expt } \\
\hline & & 6 & 8 & 9 & & \\
\hline \multirow[t]{4}{*}{ Centropages } & Ciliates & 0.62 & 0.81 & 0.85 & & \\
\hline & Phyto $_{>5 \mu \mathrm{m}}$ & 0.34 & 0.19 & 0.15 & & \\
\hline & Phyto $_{<5 \mu \mathrm{m}}$ & 0.04 & 0.00 & 0.00 & & \\
\hline & & 5 & 10 & & & \\
\hline \multirow[t]{4}{*}{ Clausocalanus } & Ciliates & 0.79 & 0.81 & & & \\
\hline & Phyto $_{>5 \mu \mathrm{m}}$ & 0.16 & 0.15 & & & \\
\hline & Phyto $_{<5 \mu \mathrm{m}}$ & 0.05 & 0.04 & & & \\
\hline & & 6 & 7 & 9 & & \\
\hline \multirow[t]{4}{*}{ Euterpina } & Ciliates & 0.67 & 0.60 & 0.70 & & \\
\hline & Phyto $_{>5} \mu \mathrm{m}$ & 0.19 & 0.40 & 0.25 & & \\
\hline & Phyto $_{<5 \mu \mathrm{m}}$ & 0.14 & 0.00 & 0.05 & & \\
\hline & & 1 & 2 & 8 & 9 & 10 \\
\hline \multirow[t]{4}{*}{ Oithona } & Ciliates & 0.95 & 0.96 & 0.47 & 0.91 & 0.86 \\
\hline & Phyto $_{>5 \mu \mathrm{m}}$ & 0.05 & 0.04 & 0.49 & 0.09 & 0.05 \\
\hline & Phyto $_{<5 \mu \mathrm{m}}$ & 0.00 & 0.00 & 0.04 & 0.00 & 0.09 \\
\hline & & 1 & 2 & 3 & 4 & \\
\hline \multirow[t]{4}{*}{ Paracalanus } & Ciliates & 0.70 & 0.65 & 0.64 & 0.30 & \\
\hline & Phyto $_{>5 \mu \mathrm{m}}$ & 0.26 & 0.34 & 0.24 & 0.64 & \\
\hline & Phyto $_{<5 \mu \mathrm{m}}$ & 0.04 & 0.01 & 0.12 & 0.06 & \\
\hline & & 5 & 10 & & & \\
\hline \multirow[t]{3}{*}{ Temora } & Ciliates & 0.55 & 0.45 & & & \\
\hline & Phyto $_{>5} \mu \mathrm{m}$ & 0.40 & 0.47 & & & \\
\hline & Phyto $_{<5} \mu \mathrm{m}$ & 0.04 & 0.08 & & & \\
\hline Cladocerans & & 1 & 7 & & & \\
\hline \multirow[t]{4}{*}{ Evadne } & Ciliates & 0.96 & 0.41 & & & \\
\hline & Phyto $_{>5} \mu \mathrm{m}$ & 0.04 & 0.05 & & & \\
\hline & Phyto $_{<5} \mu \mathrm{m}$ & 0.00 & 0.53 & & & \\
\hline & & 3 & 5 & 9 & 10 & \\
\hline \multirow[t]{4}{*}{ Penilia } & Ciliates & 0.73 & 0.56 & 0.67 & 0.66 & \\
\hline & Phyto $_{>5 \mu \mathrm{m}}$ & 0.27 & 0.00 & 0.28 & 0.30 & \\
\hline & Phyto $_{<5 \mu \mathrm{m}}$ & 0.00 & 0.44 & 0.05 & 0.04 & \\
\hline & & 6 & 7 & & & \\
\hline \multirow[t]{3}{*}{ Podon } & Ciliates & 0.58 & 0.00 & & & \\
\hline & Phyto $_{>5} \mu \mathrm{m}$ & 0.04 & 0.42 & & & \\
\hline & Phyto $_{<5 ~ \mu \mathrm{m}}$ & 0.38 & 0.58 & & & \\
\hline
\end{tabular}

instance, it is known that copepods may tend to maximise nitrogen ingestion (Houde \& Roman 1987, Cowles et al. 1988). When contributions to food rations are computed in terms of nitrogen, due to ciliate higher nitrogen contents in comparison with phytoplankton $\left(\mathrm{C}: \mathrm{N}_{\text {ciliates }}=3.5\right.$, Stoecker \& Capuzzo 1990; C: $\mathrm{N}_{\text {algae }}=6.6$, Parsons et al. 1984b), a more important role of ciliates appears, supplying on median 51 and $34 \%$ of the nitrogen intake of copepods and cladocerans, respectively. Then, nutritionally, ciliates are major contributors to the diet of zooplankton and, consequently, more attention should be paid to their effects on zooplankton metabolism. It has been speculated (Stoecker \& Capuzzo 1990, Wickham 1995) that ciliates could be a qualitatively rich source of proteins and amino acids, and that they could contain some polyunsaturated fatty acids (PUFA), considered important in the reproduction of crustaceans. However, the literature on ciliate biochemical composition is very sparse. A recent study has shown that some ciliates (i.e. Mesodinium pulex) can contain high levels of PUFA, and that the presence of these substances seems to affect egg hatching processes more than to increase egg production rates in copepods (Broglio et al. 2003). However, further research is still needed to better assess the biochemical composition of ciliates and its relationship to zooplankton nutrition and reproduction. bon intake of copepods (median: $37 \%$, range: 3 to $93 \%)$. These values are within the wide range of estimates found in the literature, ranging from studies reporting that ciliates did not contribute much to copepod diet (percentage of total carbon ingestion: $<10 \%$, Tiselius $1989 ;<6 \%$, Irigoien et al. 1998) to moderate contributions (5 to $29.2 \%$ of diet, Vincent \& Hartmann 2001; 20 to 29\%, Verity \& Paffenhöfer 1996; 0.4 to $49 \%$, Calbet et al. $2002 b$; 22 to $31 \%$, Zeldis et al. 2002) and high contributions (16 to $100 \%$, Fessenden \& Cowles 1994). Although prey contribution to the daily food rations is usually considered in terms of carbon, it is obvious that the ingestion of a prey is not only a question of one element. For

\section{Prey selection patterns and zooplankton feeding behaviour plasticity}

Most predators exhibit prey selectivity as an optimising strategy to maximise their survival and reproduction. The economics of prey choice depend on factors such as the energetic (nutritional) value of prey, handling time and encounter rate (searching time) (Krebs \& Davies 1993), although the actual prey selectivity pattern will depend also on other factors, such as the ability of prey to avoid predation. In our study, there is an overall positive selection for ciliates by crustacean mesozooplankton, corroborating previous studies, which reported similar results (e.g. Fessenden \& 
Table 6. Crustacean and ciliate abundance utilised to calculate the grazing impact. Ciliate standing stock was determined assuming a homogeneous distribution in the water column. Zooplankton predation was computed as the copepod or cladoceran abundance multiplied by their clearance rates. Grazing impact is calculated as the percentage of ciliate standing stock ingested by the crustacean community in a day, when only considering the species studied or when considering the whole crustacean community, assuming an average clearance rate for the non-studied species (see 'Materials and methods' section)

\begin{tabular}{|c|c|c|c|c|c|}
\hline Expt & $\begin{array}{l}\text { Copepod abundance } \\
\text { (ind. } \mathrm{m}^{-3} \text { ) }\end{array}$ & $\begin{array}{l}\text { Cladoceran abundance } \\
\quad \text { (ind. } \mathrm{m}^{-3} \text { ) }\end{array}$ & $\begin{array}{l}\text { Ciliate standing stock } \\
\qquad\left(\times 10^{4} \text { cells m }{ }^{-3}\right)\end{array}$ & $\begin{array}{c}\text { Grazing impact } \\
\text { (studied species) } \\
(\%)\end{array}$ & $\begin{array}{l}\text { Grazing impact } \\
\text { (whole crustacean } \\
\text { community) (\%) }\end{array}$ \\
\hline 1 & 2310 & 424 & 390 & 2.1 & 4.8 \\
\hline 2 & 3961 & 217 & 132 & 3.7 & 6.9 \\
\hline 3 & 1262 & 196 & 1940 & 0.02 & 0.4 \\
\hline 4 & 7697 & 590 & 1905 & 0.3 & 3.2 \\
\hline 5 & 5140 & 421 & 201 & 2.2 & 6.4 \\
\hline 6 & 1324 & 25 & 247 & 0.1 & 1.6 \\
\hline 7 & 521 & 165 & 530 & 0.1 & 0.8 \\
\hline 8 & 3026 & 12 & 480 & 0.6 & 3.5 \\
\hline 9 & 2109 & 335 & 1630 & 0.4 & 1.3 \\
\hline 10 & 2068 & 105 & 450 & 0.6 & 1.5 \\
\hline Median & 2210 & 206 & 470 & 0.5 & 2.4 \\
\hline
\end{tabular}

Cowles 1994, Levinsen et al. 2000). The reasons for this selection for ciliates are not completely understood. One may expect organisms to tend to optimise the ingestion of food and to minimise the energetic costs of capture. As mentioned above, consuming ciliates might signify a higher intake of nutritious organic matter than that obtained by consuming algae (excluding, perhaps, autotrophic dinoflagellates; Broglio et al. 2003). On the other hand, motility and escape reactions that some ciliates present may increase the energetic cost of capture (Jonsson \& Tiselius 1990, Burns \& Gilbert 1993) and affect capture efficiency (Broglio et al. 2001).

Optimal foraging theory predicts that a predator may switch from feeding on diverse prey (no preference) to specialise on single 'good' prey when the realised availability (encounter) of it increases. Then, the relative proportion of ciliates vs phytoplankton must generate a trade-off between energetic gains and costs of selective feeding on ciliates. We expected to observe switching responses between diets based on phytoplankton and those based on ciliates as a function of their relative abundance. However, this switch, if present, was only suggested in the case of Oithona spp., and appears to be highly species specific (i.e. Centropages typicus, Euterpina acutifrons, Paracalanus parvus and Penilia avirostris fed preferentially on ciliates in spite of high abundance of phytoplankton). Switching responses have been previously suggested in the copepod literature (e.g. Fessenden \& Cowles 1994, Levinsen et al. 2000). Such feeding plasticity could be interpreted as an adaptive response to situations of low phytoplankton availability, omnivory being unnecessary under phytoplankton bloom conditions (Fessenden \& Cowles 1994). However, such responses are not on-off responses, and they may imply a change in the prey relative contribution to diet and not necessarily the exclusion of a determined prey item.

Our data on marine cladocerans are valuable because of the scarcity of knowledge on their feeding behaviour. We observed selection for ciliates by Penilia avirostris while the few previous studies, based on laboratory experiments, indicated they are adapted to feed unselectively on small particles (Paffenhöfer \& Orcutt 1986, Turner 1988). More surprising are the results for Evadne spinifera and Podon spp, feeding preferentially on $\mathrm{Phyto}_{<5} \mu \mathrm{m}$ in most of the experiments, when these genera are typically described as raptorial feeders capable of capturing prey in a size range of 20 to $170 \mu \mathrm{m}$ (Egloff et al. 1997, and references therein). We cannot disregard, however, the possibility that complex interactions in the grazing bottles within the microbial community (trophic cascades; Calbet et al. 2001a, Nejstgaard et al. 2001) could be responsible for these apparent results of podonid feeding. Certainly, more studies are needed to better understand marine cladocerans dietary preferences, particularly because they must have a significant impact on the microzooplankton communities of stratified oligotrophic waters (Calbet et al. 2001b).

\section{Zooplankton grazing impact}

Despite crustacean zooplankton largely predated on ciliates, their grazing impact on the ciliate community appeared to be low in most cases, only $2 \%$ of the ciliate standing stock being ingested on median (over a yearly cycle of experiments) (Table 6). The studies of 
Dolan (1991) and Fessenden \& Cowles (1994) reported episodes of daily predation pressures up to 45 and $200 \%$ of ciliate standing stock. However, other previous studies, conducted in very different environments and different zooplankton communities, yielded conclusions similar to ours, with daily grazing impacts on ciliate standing stocks in the order of $5 \%$ (Atkinson 1996, Atkinson et al. 1996, Lonsdale et al. 2000, Batten et al. 2001, Calbet et al. 2002b, Zeldis et al. 2002). In those studies, and in ours as well, feeding rates on ciliates were high, the low grazing impact appearing to be the mere result of the low ciliate abundance in the field. Our results show higher grazing impacts when ciliate concentrations were not especially high, the alternate food source was scarce, and the crustacean predators were particularly abundant. All this evidence suggests that the top-down control exerted by zooplankton might manifest itself only in those periods when ciliates are the almost exclusive prey. In periods of low ciliate abundance, but presence of alternate prey, mesozooplankton would not exert any relevant pressure on them. Overall, the low impacts observed indicate that mesozooplankton was not able to control ciliate populations in the studied systems, suggesting a bottom-up control of them. In that case, an interesting and likely consequence would be that zooplankton might be taking up a large fraction of this resourcelimited ciliate production. However, estimates of ciliate growth rate in the Western Mediterranean (from negligible up to values of about $0.5 \mathrm{~d}^{-1}$; Pérez et al. 1997 , their Table 2) indicate, on average, daily increments in the standing stock of about $26 \%$, much higher than the losses due to zooplankton grazing we have estimated.

As a final remark, we should draw the attention to the fact that other factors, not fully considered neither in our study nor in other previous studies, could potentially enhance the role of zooplankton in exerting a predation control on ciliate communities. First, most studies have contemplated only copepods as potential predators, while other zooplankters, with major or minor dominance, might be also able to predate on them (e.g. cladocerans, this study). Within copepods, although small copepodites and nauplii are able to feed on ciliates, they are usually undersampled (Calbet et al. 2001b, Gallienne \& Robins 2001) and negligently contemplated in budgets (but see Dolan 1991, where Acartia tonsa nauplii can account for up to $200 \%$ of the ciliate standing stock in Chesapeake Bay; and Merrell \& Stoecker 1998, where Eurytemora affinis nauplii can account for up to $56 \%$ of total copepod grazing impact on ciliates respectively). A second factor to be considered is the attribute of plankters to aggregate in patches (Mackas 1985, Davis et al. 1991, Montagnes et al. 1999) and the ability of copepods to find them and remain in them (Tiselius 1992, Saiz et al. 1993). Most evaluations of grazing impact on ciliates are based on the assumption of homogenous distribution of predators and prey, whereas heterogeneous distributions can render much higher impacts (Mullin \& Brooks 1976). Finally, standard incubations to determine grazing rates of zooplankton are conducted under conditions of absence of small-scale turbulence, while one ubiquitous characteristic of the oceans is the presence of turbulence. Saiz \& Kiørboe (1995) and Caparroy et al. (1998) found that moderated turbulence levels enhanced up to 3 times the feeding rates of Acartia tonsa and Centropages typicus on ciliates. Actually, Saiz \& Kiørboe (1995) and Kiørboe et al. (1996) proposed that turbulence may induce a change in selective patterns, shifting copepod feeding behaviour towards a ciliate diet. The consideration of this turbulence enhancement of feeding on ciliates, if extended to other zooplankters, would drastically increase the predation pressure on them.

Acknowledgements. The authors are very much indebted to Sergi de la Peña and Noèlia Arco for their technical assistance and enthusiasm. The Captain and crew of the harbour of Masnou kindly provided facilities and access to the sea. We dedicate this work to the late Mr. Manuel Brenes Salvatierra, sailor from this harbour, who for more than 15 years helped us at sea. This study was supported financially by the Spanish grants SERET (MAR98-0854) and ZOOTRANSFER (REN2001-1693; www.icm.csic.es/bio/projects/zootransfer, and by the Programa Ramón y Cajal through a contract to A.C.

\section{LITERATURE CITED}

Arin L, Morán XAG, Estrada M (2002) Phytoplankton size distribution and growth rates in the Alboran Sea (SW Mediterranean): Short-term variability related to mesoscale hydrodynamics. J Plankton Res 24:1019-1033

Atkinson A (1996) Subantartic copepods in an oceanic, low chlorophyll environment: ciliate predation, food selectivity and impact on prey populations. Mar Ecol Prog Ser 130: 85-96

Atkinson A, Shreeve RS, Pakhomov EA, Priddle J, Blight SP, Ward P (1996) Zooplankton response to a phytoplankton bloom near South Georgia, Antarctica. Mar Ecol Prog Ser 144:195-210

Azam F, Fenchel F, Field T, Gray JG, Meyer-Reil JS, Thingstad LA (1983) The ecological role of water-column microbes in the sea. Mar Ecol Prog Ser 10:257-263

Batten SD, Fileman ES, Halvorsen E (2001) The contribution of microzooplankton to the diet of mesozooplankton in an upwelling filament off the north west coast of Spain. Prog Oceanogr 51:385-398

Broglio E, Johansson M, Jonsson PR (2001) Trophic interaction between copepods and ciliates: effects of prey swimming behavior on predation risk. Mar Ecol Prog Ser 220:179-186

Broglio E, Jonasdóttir S, Calbet A, Jakobsen HH, Saiz E (2003) The effect of heterotrophic versus autotrophic food on feeding and reproduction of the calanoid copepod Acartia tonsa Dana: relationship with prey fatty acid 
composition. Aquat Microb Ecol 31:267-278

Burns CW, Gilbert JJ (1993) Predation on ciliates by freshwater calanoid copepods: rates of predation and relative vulnerabilities of prey. Freshw Biol 30:377-393

Calbet A, Landry MR, Nunnery S (2001a) Bacteria-flagellate interactions in the microbial food web of the oligotrophic subtropical North Pacific. Aquat Microb Ecol 23:283-292

Calbet A, Garrido S, Saiz E, Alcaraz M, Duarte CM (2001b) Annual zooplankton succession in coastal NW Mediterranean waters: the importance of the smaller size fractions. J Plankton Res 23:319-331

Calbet A, Saiz E, Alcaraz M (2002a) Copepod egg production in the NW Mediterranean: effects of winter environmental conditions. Mar Ecol Prog Ser 237:173-184

Calbet A, Broglio E, Saiz E, Alcaraz M (2002b) Low grazing impact of mesozooplankton on the microbial communities of the Alboran Sea: a possible case of inhibitory effects by the toxic dinoflagellate Gymnodinium catenatum. Aquat Microb Ecol 26:235-246

Caparroy P, Perez MT, Carlotti F (1998) Feeding behaviour of Centropages typicus in calm and turbulent conditions. Mar Ecol Prog Ser 168:109-118

Chesson J (1983) The estimation and analysis of preference and its relationship to foraging models. Ecology 64: 1297-1304

Chisholm LA, Roff JC (1990) Size-weight relationships and biomass of tropical neritic copepods off Kingston, Jamaica. Mar Biol 106:71-77

Cowles TJ, Olson RJ, Chisholm SW (1988) Food selection by copepods: discrimination on the basis of food quality. Mar Biol 100:41-49

Dam HG, Peterson WT, Bellantoni DC (1994) Seasonal feeding and fecundity of the calanoid copepod Acartia tonsa in Long Island Sound: Is omnivory important to egg production? Ecology and morphology of copepods. Hydrobiology 292-293:191-199

Davis CS, Alatalo P (1992) Effects of constant and intermittent food supply on life-history parameters in a marine copepod. Limnol Oceanogr 37:1618-1639

Davis CS, Flierl GR, Wiebe PH, Franks PJS (1991) Micropatchiness, turbulence and recruitment in plankton. J Mar Res 49:109-151

Delgado M, Latasa M, Estrada M (1992) Variability in the size-fractionated distribution of the phytoplankton across the Catalan front of the north-west Mediterranean. J Plankton Res 14:753-771

Dolan JR (1991) Microphagous ciliates in mesohaline Chesapeake Bay waters: estimates of growth rates and consumption by copepods. Mar Biol 111:303-309

Egloff DA, Fofonoff PW, Onbé T (1997) Reproductive biology of marine cladocerans. Adv Mar Biol 31:79-168

Fessenden L, Cowles $\mathrm{T}$ (1994) Copepod predation on phagotrophic ciliates in Oregon coastal waters. Mar Ecol Prog Ser 107:103-111

Finlay BJ, Fenchel T (1996) Ecology: role of ciliates in the natural environment. In: Hausmann K, Bradbury PC (eds) Ciliates. Cells as organisms. Gustav Fisher, Stuttgart, p $417-440$

Froneman PW, Pakhomov EA, Perissinotto R, McQuaid CD (1996) Role of microplankton in the diet and daily ration of Antarctic zooplankton species during austral summer. Mar Ecol Prog Ser 143:15-23

Frost BW (1972) Effects of size and concentration of food particles on the feeding behavior of the marine planktonic copepod Calanus pacificus. Limnol Oceanogr 17:805-815

Gallienne CP, Robins DB (2001) Is Oithona the most important copepod in the world's oceans? J Plankton Res 23:
$1421-1432$

Gifford DJ, Dagg MJ (1991) The microzooplankton-mesozooplankton link: consumption of planktonic protozoa by the calanoid copepods Acartia tonsa Dana and Neocalanus plumchrus Murukawa. Mar Microb Food Webs 5:161-177

Gismervik I, Andersen T (1997) Prey switching by Acartia clausi: experimental evidence and implications of intraguild predation assessed by a model. Mar Ecol Prog Ser 157:247-259

Houde SEL, Roman MR (1987) Effects of food quality on the functional ingestion response of the copepod Acartia tonsa. Mar Ecol Prog Ser 40:69-77

Irigoien X, Head R, Klenke U, Meyer Harris B, Harbour D, Niehoff B, Hirche HJ (1998) A high frequency time series at weathership M, Norwegian Sea, during the 1997 spring bloom: feeding of adult female Calanus finmarchicus. Mar Ecol Prog Ser 172:127-137

Jonsson PR, Tiselius P (1990) Feeding behavior, prey detection and capture efficiency of the copepod Acartia tonsa feeding on planktonic ciliates. Mar Ecol Prog Ser 60:35-44

Kiørboe T, Møhlenberg F, Hamburger K (1985) Bioenergetics of the planktonic copepod Acartia tonsa: relation between feeding, egg production and respiration, and composition of specific dynamic action. Mar Ecol Prog Ser 26:85-97

Kiørboe T, Saiz E, Viitasalo M (1996) Prey switching behavior in the planktonic copepod Acartia tonsa. Mar Ecol Prog Ser 143:65-75

Klein Breteler WCM, Schogt N, González SR (1990) On the role of food quality in grazing and development of life stages and genetic change of body size during cultivation of pelagic copepods. J Exp Mar Biol Ecol 135:177-189

Krebs JR, Davies NB (1993) An introduction to behavioural ecology. Blackwell Scientific Publications, Oxford

Levinsen H, Turner JT, Nielsen TG, Hansen BW (2000) On the trophic coupling between protists and copepods in arctic marine ecosystems. Mar Ecol Prog Ser 204:65-77

Lonsdale D, Caron DA Dennett MR, Schaffner R (2000) Predation by Oithona spp on protozooplankton in the Ross Sea, Antarctica. Deep-Sea Res II 47:3273-3283

Mackas DL, Denman KL, Abbott MR (1985) Plankton patchiness: biology in the physical vernacular. Bull Mar Sci 37: 652-674

Merrell JR, Stoecker DK (1998) Differential grazing on protozoan microplankton by developmental stages of the calanoid copepod Eurytemora affinis Poppe. J Plankton Res 20:289-304

Modigh M (2001) Seasonal variations of photosynthetic ciliates at a Mediterranean coastal site. Aquat Microb Ecol 23:163-175

Montagnes DJS, Poulton AJ, Shammon TM (1999) Mesoscale, finescale and microscale distribution of micro- and nanoplankton in the Irish Sea, with emphasis on ciliates and their prey. Mar Biol 134:167-179

Mullin MM, Brooks ER (1976) Some consequences of distributional heterogeneity of phytoplankton and zooplankton. Limnol Oceanogr 21:784-796

Nejstgaard JC, Naustvoll LJ, Sazhin A (2001) Correcting for underestimation of microzooplankton grazing in bottle incubation experiments with mesozooplankton. Mar Ecol Prog Ser 221:59-75

Ohman M, Runge JA (1994) Sustained fecundity when phytoplankton resources are in short supply: omnivory by Calanus finmarchicus in the Gulf of St. Lawrence. Limnol Oceanogr 39:21-36

Paffenhöfer GA, Orcutt JD Jr (1986) Feeding, growth and food conversion of the marine cladoceran Penilia avirostris. J Plankton Res 8:741-754 
Parsons TR, Maita Y, Lalli CM (1984a) A manual of chemical and biological methods for seawater analysis. Pergamon Press, Oxford

Parsons TR, Takahashi M, Hargrave B (1984b) Biological oceanographic processes, 3rd edn. Pergamon Press, Oxford

Pérez MT, Dolan JR, Fukai E (1997) Planktonic oligotrich ciliates in the NW Mediterranean: growth rates and consumption by copepods. Mar Ecol Prog Ser 155:89-101

Pitta P, Giannakourou A (2000) Planktonic ciliates in the oligotrophic Eastern Mediterranean: vertical, spatial distribution and mixotrophy. Mar Ecol Prog Ser 194:269-282

Putt M, Stoecker DK (1989) An experimentally determined carbon: Volume ratio for marine 'oligotrichous' ciliates from estuarine and coastal waters. Limnol Oceanogr 34: 1097-1103

Saiz E, Kiørboe T (1995) Predatory and suspension feeding of the copepod Acartia tonsa in turbulent environments. Mar Ecol Prog Ser 122:147-158

Saiz E, Tiselius P, Jonsson PR, Verity P, Paffenhöfer GA (1993) Experimental records of the effects of food patchiness and predation on egg production of Acartia tonsa. Limnol Oceanogr 38:280-289

Saiz E, Calbet A, Irigoien X, Alcaraz M (1999) Copepod egg production in the western Mediterranean: response to food availability in oligotrophic environments. Mar Ecol Prog Ser 187:179-189

Satapoomin S (1999) Carbon content of some common tropical Andaman Sea copepods. J Plankton Res 21:2117-2123

Sherr E, Sherr B (1988) Role of microbes in pelagic food webs: a revised concept. Limnol Oceanogr 33:1225-1227

Sherr EB, Sherr BF, Paffenhöfer GA (1986) Phagotrophic protozoa as food for metazoans: a missing link in marine pelagic food webs? Mar Microb Food Webs 1:61-80

Stoecker DK, Capuzzo J (1990) Predation on Protozoa: its importance to zooplankton. J Plankton Res 12:891-908

Stoecker DK, Egloff DA (1987) Predation by Acartia tonsa Dana on planktonic ciliates and rotifers. J Exp Mar Biol Ecol 110:53-68

Stoecker DK, Gifford DJ, Putt M (1994) Preservation of

Editorial responsibility: John Dolan,

Villefrance-sur-Mer, France marine planktonic ciliates: losses and cell shrinkage during fixation. Mar Ecol Prog Ser 110:293-299

Tiselius P (1989) Contribution of aloricate ciliates to the diet of Acartia clausi and Centropages hamatus in coastal waters. Mar Ecol Prog Ser 56:49-56

Tiselius P (1992) Behavior of Acartia tonsa in patchy food environments. Limnol Oceanogr 37:1640-1651

Turner JT (1988) The marine cladoceran Penilia avirostris and the 'microbial loop' of pelagic food webs. Limnol Oceanogr 32:245-255

Uye S (1982) Length-weight relationships of important zooplankton from the Inland Sea of Japan. J Oceanogr Soc Jpn 38:149-158

Uye S (1991) Temperature-dependent development and growth of the planktonic copepod Paracalanus sp. in the laboratory. Bull Plankton Soc Jpn (Spec Vol) 627-636

Uye S, Sano K (1998) Seasonal variations in biomass, growth rate and production rate of the small cyclopoid copepod Oithona davisae in a temperate eutrophic inlet. Mar Ecol Prog Ser 163:37-44

Vaqué D, Blough HA, Duarte CM (1997) Dynamics of ciliate abundance, biomass and community composition in an oligotrophic coastal environment (NW Mediterranean). Aquat Microb Ecol 12:71-83

Verity PG, Paffenhöfer GA (1996) On assessment of prey ingestion by copepods. J Plankton Res 18:1767-1779

Vincent D, Hartmann HJ (2001) Contribution of ciliated microprotozoans and dinoflagellates to the diet of three copepod species in the Bay of Biscay. Hydrobiology 443: 193-204

Walve J, Larsson U (1999) Carbon, nitrogen and phosphorus stoichiometry of crustacean zooplankton in the Baltic Sea: implications for nutrient recycling. J Plankton Res 21: 2309-2321

Wickham SA (1995) Cyclops predation on ciliates: speciesspecific differences and functional responses. J Plankton Res 17:1633-1646

Zeldis J, James MR, Grieve J, Richards L (2002) Omnivory by copepods in the New Zealand Subtropical Frontal Zone. J Plankton Res 24:9-23

Submitted: March 15, 2003; Accepted: October 22, 2003

Proofs received from author(s): March 1, 2004 